\section{La renovación de la arquitectura religiosa en Portugal durante el siglo XX}

\author{
The Renewal of Religious Architecture in Portugal \\ during the 20th Century
}

MANUEL VIEIRA FERREIRA

https://doi.org/10.17979/aarc.2007.1.0.5028

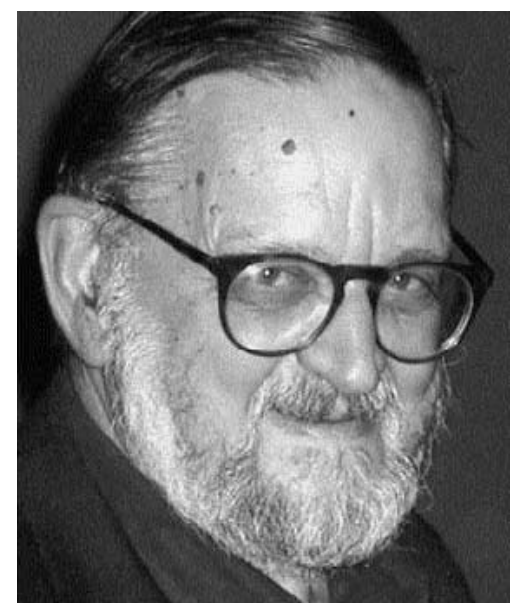

El arquitecto portugués Nuno Teotonio Pereira (1922).
El análisis que haré de la renovación de la arquitectura religiosa en Portugal durante el siglo XX es uno de los muchos modos posibles de enfrentarse con este tema. Partiré de un arquitecto, Nuno Teotonio Pereira y de tres obras, tres iglesias que él proyectó. Pienso que es un punto de vista posible, que refleja bien la intención y el fuerte deseo de cambiar la arquitectura religiosa que existía en Portugal, también por ser el primer intento serio que se hizo, digamos, en el ámbito de la segunda modernidad. La primera modernidad, que se desarrolló durante los años veinte y treinta, tiene en Portugal algunos ejemplos de este tipo, pero son pocos. En una segunda oleada, durante los años cuarenta y cincuenta, aparece Nuno Teotonio Pereira, un joven arquitecto que obtiene el título en 1948 y ya en 1949 proyecta un templo que es muy significativo de esta voluntad de cambiar la forma de proyectar y construir iglesias.

Durante el siglo XX, la arquitectura religiosa en Portugal es una continuación de la del siglo XIX. A falta de un estilo definido, se realizan proyectos de iglesias en todos los estilos históricos, como también sucedió aquí, en España, siguiendo un eclecticismo historicista y una imitación servil del pasado, de las iglesias clásicas. Las iglesias proyectadas entre 1910 y 1920 eran todas prácticamente iguales a las iglesias clásicas. En los años treinta hay un intento de incorporar al Movimiento Moderno dos iglesias que coinciden en su advocación a Nuestra Señora de Fátima, tras las apariciones de 1917: una en Oporto, proyectada por el grupo de arquitectos ARS, y otra en Lisboa, diseñada por el arquitecto Porfirio Pardal Monteiro. Estas tentativas no llegaron a buen puerto, tal vez debido a las mentalidades acaso muy atadas al pasado, y posiblemente también a la acción del régimen de Salazar, que desconfiaba de la
The analysis I intend to make about the renewal of religious architecture in Portugal during the 20th century is one of the many possible ways to tackle that topic. I will start with an architect, Nuno Teotonio Pereira, and three works, three churches that he projected. I think that this is one of the possible viewpoints, since it reflects well the intention and the strong desire to change religious architecture which existed in Portugal. It was also the first serious attempt made, let us say, in the context of the second modernity. The first modernity which evolved in the 20s and 30s in Portugal has some examples of that kind, but just a few. There was a second wave in the 40s and 50s during which Nuno Teotonio Pereira appeared. He was a young architect who graduated in 1948 and projected his first temple in 1949, which greatly signifies that will to change the way in which they project and build churches.

During the 20th century, religious architecture in Portugal was a continuation of the 19th century. Lacking a definite style, church projects are made in every historical style, as it happened also here in Spain, following a historical eclecticism and a servile imitation of the past, of the classical churches. The churches built between 1910 and 1920 were all practically the same as classical churches. They tried to incorporate to the Modern Movement in the 30 a couple of churches coinciding in their vocation: Our Lady of Fatima, after the 1917 appearances: the first one in Porto, projected by the ARS architects' group, and the 
second one in Lisbon, designed by architect Porfirio Pardal Monteiro. These attempts were failed, perhaps due to a frame of mind excessively linked to the past, and also possibly due to the action of the Salazar's regime, which distrusted foreign modern architecture. They feared that architecture and favoured a vernacular one, the national style, the Portuguese style, the so-called New State Architecture, scarcely studied so far: the regime's architecture.

Some young and non-conformist architects protested during the 40s in some paper and magazine articles against the situation of Portuguese architecture, and, in particular, of religious architecture, which they call a lie and a masquerade. I was at Teotonio Pereira's workshop last year discussing several episodes of this fight against the architecture of lies and masquerades. Teotonio and an architect friend of his - João Correia Robelo, who died in Canada - published some brochures and paper articles against this lie. What did the lie consist of? It consisted of projecting using modern materials for the classical style: for instance, making arches and domes of armoured concrete. You should not build in the old fashion with modern materials. It is a lie. We should build modern and appropriate shapes with modern materials. Making an arch of armoured concrete and later trying to make it appear as stone is a lie.

Nuno Teotonio Pereira - who is still active, thankfully, though quite old - was born in Lisbon in 1922, and he got his diploma at the Lisbon Fine Arts School in 1948. He practised the new attitude which he defended for religious architecture in 1949. He is commissioned a project for the village of Aguas, in Penamacor, in the interior part of the country. He projected a notorious church wishing to remain true to the architectural truth, to the function and to the spirit of Gospel, as well as to the character of the region, both as regards materials — as we shall see - and their integration on site. He was lucky to have been invited to do this church, and also because the church would be financed by a rich family. Thus, he could have more freedom for doing that church, although he also lived and talked with the community. However, it was not the community who paid, it was the family, therefore, the architect had more chances to do what he liked, to practise what he had so often claimed in the papers, in brochures, against traditional architecture.

The Movement for the Renewal of Religious Art (MRAR) appeared in the 50s. This movement was established by architects, painters, sculptors and historians. Nuno Teotonio Pereira was part of that group from the very beginning and was also the chairman for several years. The MRAR was active for two decades, the 50s and 60s, and contributed greatly to the renewal of religious arquitectura moderna que venía del extranjero. Temía esa arquitectura, prefería una arquitectura vernácula, el estilo nacional, el estilo portugués, que se tradujo en la llamada arquitectura del Estado Novo, todavía poco estudiada: la arquitectura del Régimen.

En los años cuarenta, algunos jóvenes arquitectos - siempre inconformistas - protestan en artículos de revistas y periódicos contra la situación de la arquitectura en Portugal, y en particular, de la arquitectura religiosa, que tildan de «mentira y mascarada». Precisamente, el pasado año estuve en el estudio de Teotonio Pereira hablando de diversos episodios de esta lucha contra la arquitectura de la mentira y de la mascarada. Teotonio y un arquitecto amigo suyo - Joao Correia Robelo, que ya murió, en Canadá- publicaron en algunos folletos y en periódicos textos contra esta mentira. ¿Y en qué consistía esta mentira? En proyectar en el estilo clásico con materiales modernos: por ejemplo, hacer arcos y bóvedas en hormigón armado. Es una mentira. No se debe construir con materiales modernos a la manera antigua. Debemos construir con materiales modernos formas modernas, adecuadas. Hacer un arco en hormigón armado y después hacerlo parecer de piedra era una mentira.

Nuno Teotonio Pereira - felizmente todavía activo, aunque ya bastante mayor- nació en Lisboa en 1922, se diplomó en la Escuela de Bellas Artes de Lisboa en 1948. En 1949 pone en práctica la nueva actitud que defiende para la arquitectura religiosa. Le piden un proyecto para la aldea de Aguas, en Penamacor, en el interior del país. Proyecta una iglesia notable que quiere ser fiel a la verdad arquitectónica, a la función, al espíritu del Evangelio y al carácter de la región, tanto en los materiales - como vamos a ver- como en la integración en el lugar. Tiene suerte de ser invitado para hacer esta iglesia, también por el hecho de que iba a ser costeada por una familia rica. Así, él puede hacer la iglesia con más libertad, aunque también habló y convivió con la comunidad. Pero no era la comunidad la que pagaba: era la familia. Y por tanto, el arquitecto, en cierta forma, tuvo más posibilidades de hacer lo que quería, de poner en práctica aquello que tanto había proclamado en los periódicos, en los panfletos, contra la arquitectura tradicional.

En los años cincuenta surge el Movimiento de Renovación del Arte Religioso (MRAR). Este movimiento fue fundado por arquitectos, pintores, escultores e historiadores. Nuno Teotonio Pereira se incluye en este grupo desde el primer momento y lo preside durante varios años. El MRAR, cuya actividad se desplegó durante dos décadas - los cincuenta y los sesenta-, contribuyó mucho a la renovación de la arquitectura religiosa por las vastas iniciativas que desarrollaba, desde reuniones periódicas de investigación hasta análisis de proyectos de iglesias presentados por sus propios autores: el arquitecto llegaba, presentaba su proyecto, oía las críticas, discutía el proyecto, etc. Hacían también retiros y publicaciones regulares —un boletín, estampas por Navidad por Pascua-, acompañamiento de concursos de nuevas iglesias cuando se lo solicitaban, etc. 

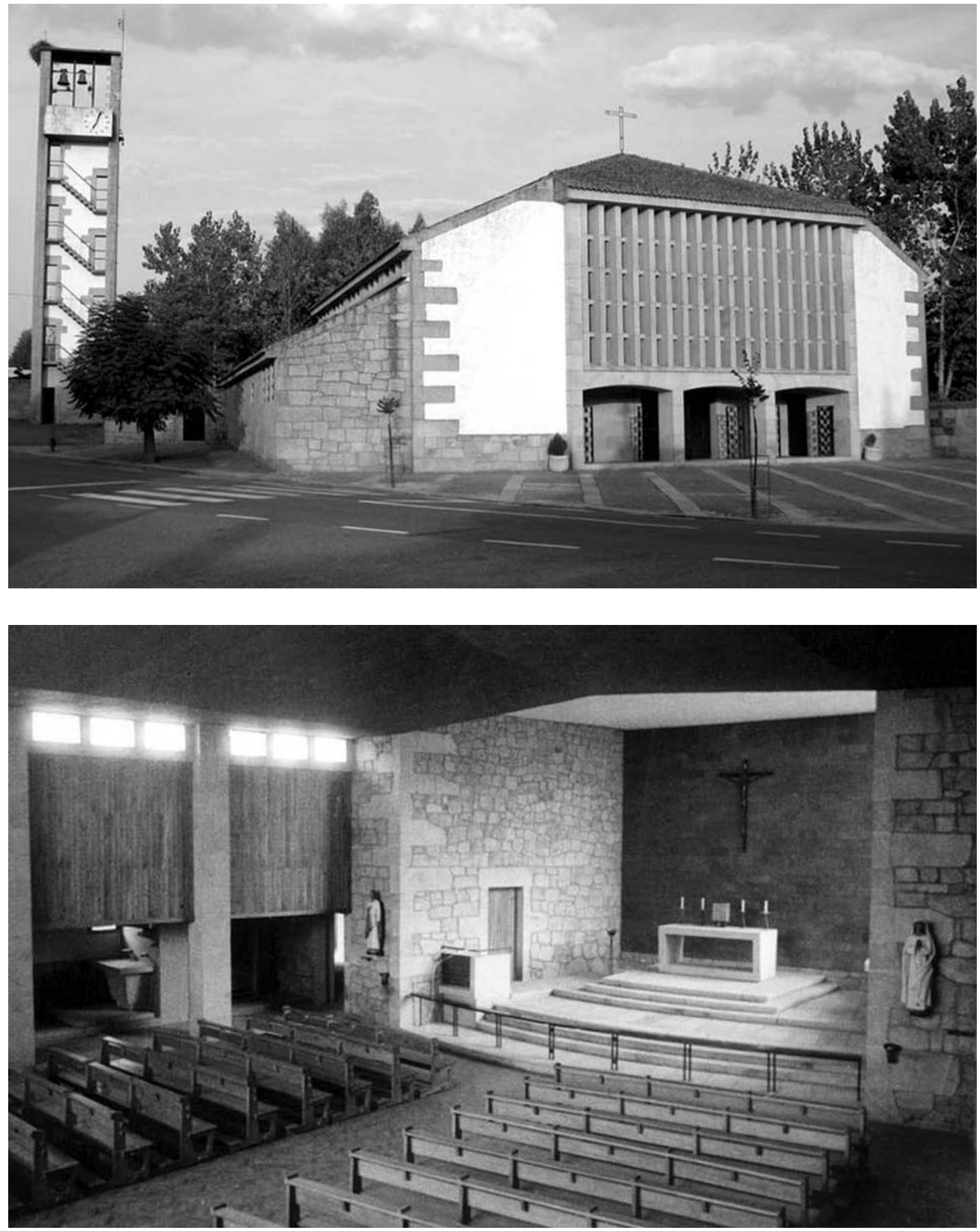

Nuno Teotonio Pereira, iglesia parroquial de Aguas, Penamacor, 1949/59. 


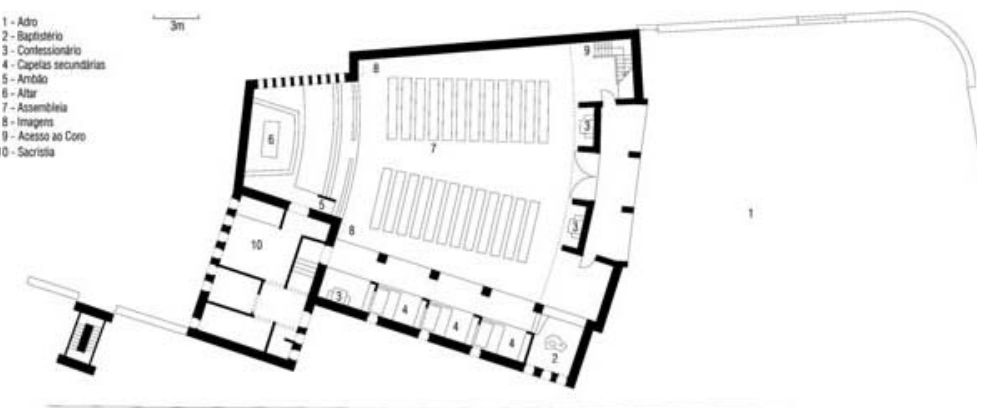

Nuno Teotonio Pereira, iglesia parroquial de Aguas, Penamacor, 1949/59.

architecture thanks to the numerous initiatives it launched, ranging from periodical research meetings to the analysis of church projects presented by its authors: architects would present their projects, listen to the criticisms, discuss the projects, etc. They would also organise trips and regular publications - a newsletter, postcards at Christmas and Easter-, together with contests for new churches when it was requested, etc.

Let us analyse the architectural renewal from the already-mentioned perspective: based on three churches from different periods, of the same parish type and by the same author, Nuno Teotonio Pereira.

The first church that I mentioned was the one in Aguas, a pioneer church in the renewal. Then we will take a look at the church of the Sacred Heart of Jesus, also a parish church but with a totally different form: a parish in downtown Lisbon, right next to Avenida da Liberdade, built in 1962 as a statement and confirmation of an already established new architectural reality. Finally, a church in a different context, located in a workingclass district in the outskirts of Lisbon: Almada, projected in the late 60s and which continued to be built along the 70s, showing a great concern with the social movement.

The church of Aguas has a very small plan, with the altar, the pulpit, two sculptures - of Our Lady and Jesus Christ-on both sides, two confessional booths plus another one further away, three side altars in three chapels - one of them being the Holy Sacrament chapel-and the baptismal font at the back. The choir is above the entrance, still faithful to tradition, and the sacristy beyond it. You can see
Analicemos ahora la renovación arquitectónica desde la perspectiva que enuncié al principio, partiendo de tres iglesias de periodos diferentes, de la misma tipología parroquial y del mismo autor, Nuno Teotonio Pereira.

La primera iglesia, a la que ya me referí, es la de Aguas, una iglesia pionera de la renovación. Después veremos la iglesia del Sagrado Corazón de Jesús, también parroquial pero con una forma totalmente diversa: una parroquia en el centro de Lisboa, justo al lado de la Avenida da Liberdade, de 1962, afirmación y confirmación de una nueva realidad arquitectónica ya implantada. Finalmente, una iglesia en un contexto diferente, en una villa en crecimiento, una ciudad dormitorio de Lisboa: Almada, proyectada al final de la década de los sesenta y cuya construcción se prolongaría en la década de los setenta, con una gran preocupación por el movimiento social.

La planta de la iglesia de Aguas es muy pequeña, con el altar, el ambón, dos imágenes - de Nuestra Señora y de Jesucristo - a los lados, dos confesionarios y otro más, separado, tres altares laterales en otras tantas capillas — una de ellas la capilla del Santísimo - y al fondo la pila bautismal. Encima de la entrada aparece el coro, todavía fiel a la tradición, y más allá la sacristía. La planta, como pueden ver, presenta una innovación: las líneas convergentes. No era costumbre este tipo de planta en Portugal. Mientras tanto, sigue apareciendo la longitudinalidad de la asamblea.

La construcción duró bastantes años y la iglesia se inauguró en 1958 ó 1959. La fachada principal de la iglesia tiene una entrada de luz que ilumina el coro y la nave; una luz controlada. En el primer proyecto, la torre de las campanas estaba en un sitio distinto, pero finalmente el arquitecto decidió hacerla atrás. La cubierta es inclinada para integrarse en el contexto; el granito es el material principal y las capillas laterales tienen entradas de luz por la parte superior de las paredes. El granito también está presente en todo el atrio. Actualmente la iglesia se conserva bastante bien. La entrada de luz 

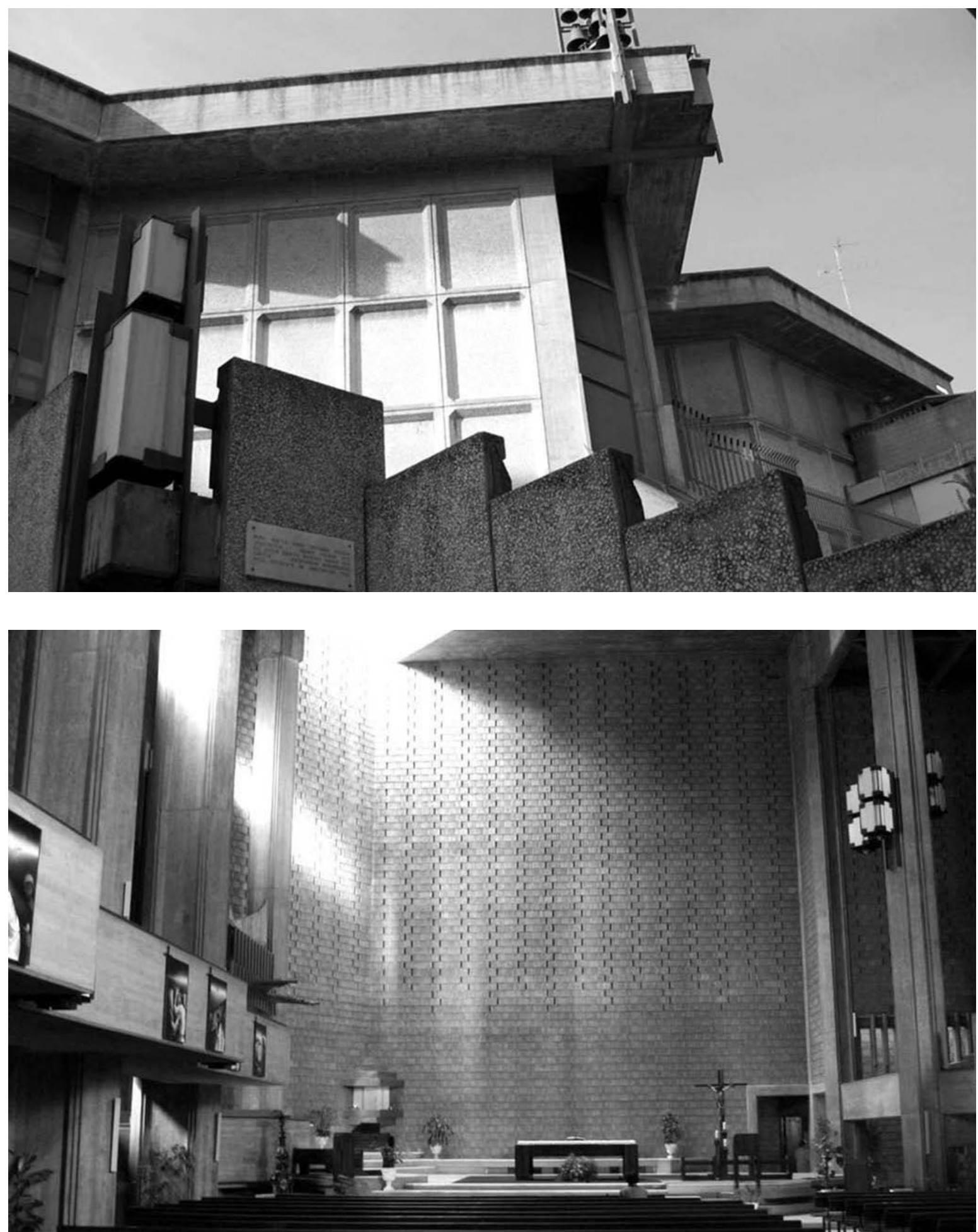

Nuno Teotonio Pereira y Nuno Portas, iglesia del Sagrado Corazón de Jesús, Lisboa, 1962/70. 


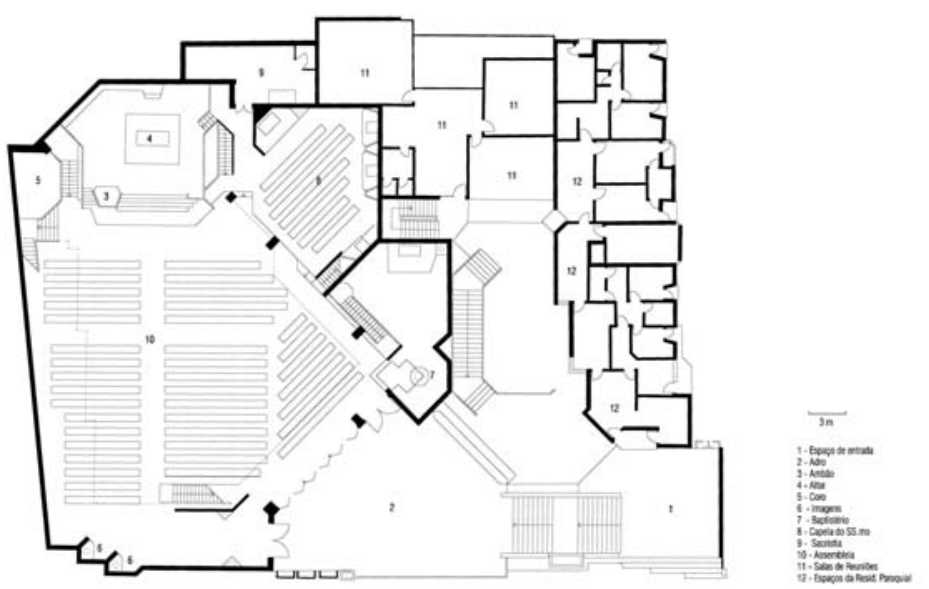

Nuno Teotonio Pereira y Nuno Portas, iglesia del Sagrado Corazón de Jesús, Lisboa, 1962/70.

that there is an innovation in the plan: converging lines. This kind of plan was not usual in Portugal. Meanwhile, the assembly remains longitudinal. It took many years to build it and the church was opened in 1958 or 1959. The church main façade has a light opening throwing light upon the choir and nave, a well-controlled light. In the first project, the belfry was somewhere else but finally, the architect decided to build it at the back. The roof is slanted so as to fit within the context; granite is the main material and the side chapels have light openings at the top of the walls. Granite is also present in the whole atrium. Currently, the church is quite well preserved. The side light opening at the presbytery was carefully studied and argued by the architect in the project descriptive report. The interior provides devotion and privacy; a significant lack of white can be perceived there, as opposed to the natural colours of wood and granite. The back wall is painted in dark red. All of this provides a certain harmony and nobility to the space. Finally, this is a continuity church with a certain degree of innovation.

In the case of the Lisbon church, it is made of armoured concrete and has a light opening above the presbytery. A balcony wholly surrounds the nave. The Holy Sacrament chapel is at a lower level, at the priests' demand. There is a mortuary chapel, a conference hall and a wedding chapel which complete the programme. The plot was small and the only one available downtown, therefore a tall building had to be made creating an entrance atrium. Quite a big parish complex saves the considerable slope in the plot. The zenith light falling over the presbytery creates the right lateral del presbiterio se estudió detenidamente y fue muy argumentada por el arquitecto en la memoria descriptiva del proyecto. El espacio interior ofrece recogimiento e intimidad; se puede percibir en él la significativa ausencia del color blanco, frente a los colores naturales de la madera o del granito. La pared del fondo está pintada de un tono rojo oscuro. Todo ello aporta una cierta armonía y nobleza al espacio. En definitiva, estamos ante una iglesia continuísta pero con alguna innovación.

En el caso de la iglesia de Lisboa, la iglesia está construida en hormigón armado y tiene una entrada de luz sobre el presbiterio. Un balcón rodea completamente la nave. La capilla del Santísimo se encuentra en una cota inferior, por exigencia de los sacerdotes. Una capilla mortuoria, un salón de actos y una capilla para bodas completan el programa. El solar era pequeño, el único disponible en el centro de la ciudad, por lo que hubo que hacer un edificio en altura creando un atrio de entrada. Un complejo parroquial muy grande salva el importante desnivel del solar. La luz cenital que cae sobre el presbiterio crea una atmósfera propicia para el recogimiento, ayudada por el control de las proporciones del espacio. El coro se encuentra en la parte más elevada y vincula el presbiterio con la asamblea. En esta iglesia de 1962 ya está muy presente la renovación litúrgica: el arquitecto la tiene en cuenta y la estudia con mucho cuidado.

La tercera y última iglesia es la de Almada. Es una iglesia diferente, en anfiteatro, con varios niveles (hasta cuatro), donde ya está completamente aplicada la nueva liturgia, con el altar, la sede presidencial, el ambón, etc. muy estudiados. Incluso hay un sitio preciso para el director del coro. La capilla del Santísimo se encuentra en un lateral. También hay una capilla privada, salas de catequesis y un atrio. Hay que destacar el austero hormigón armado de textura muy poderosa, dejado a la vista 

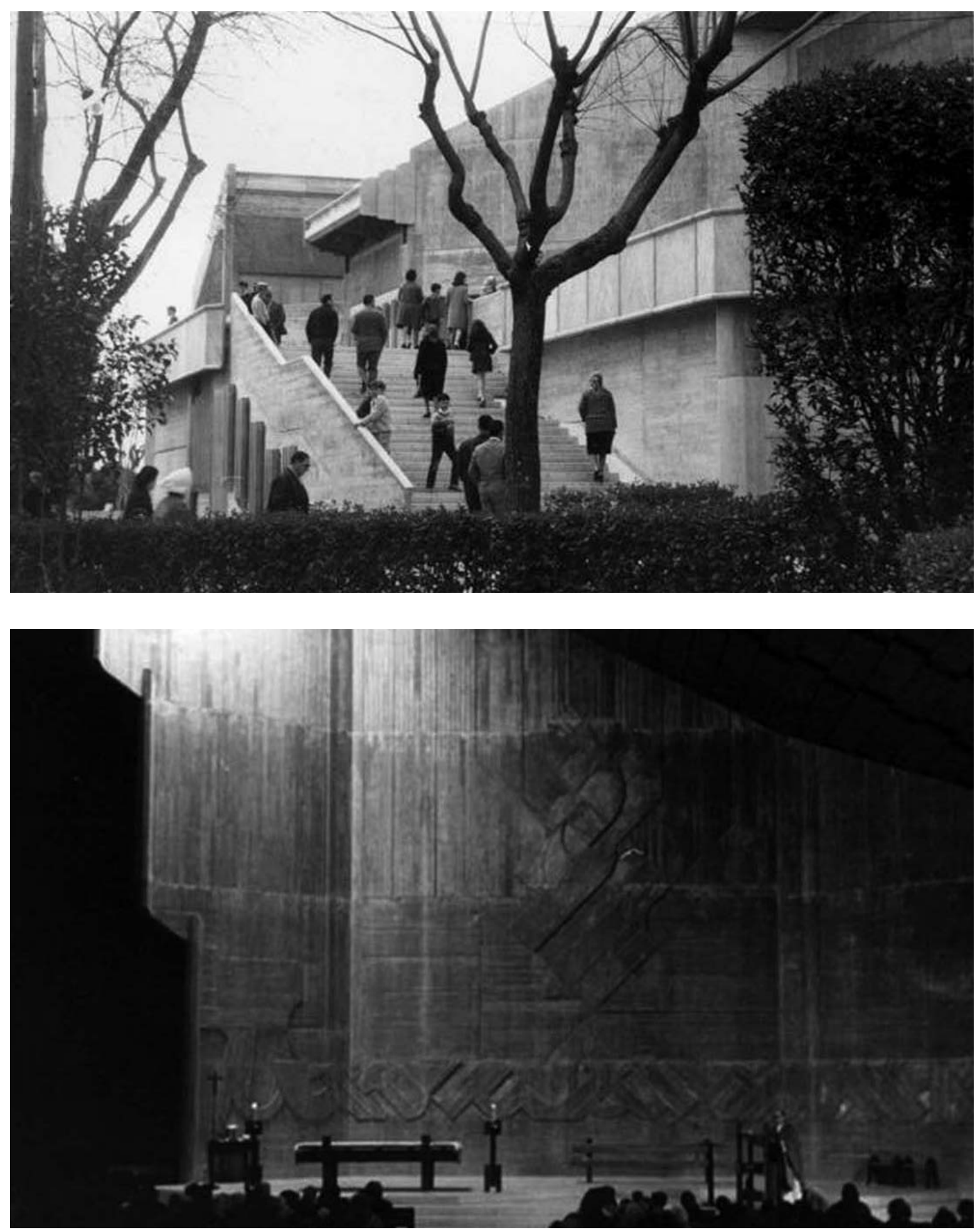

Nuno Teotonio Pereira y Luis Almeida Moreira, iglesia parroquial de Almada, 1965/67. 


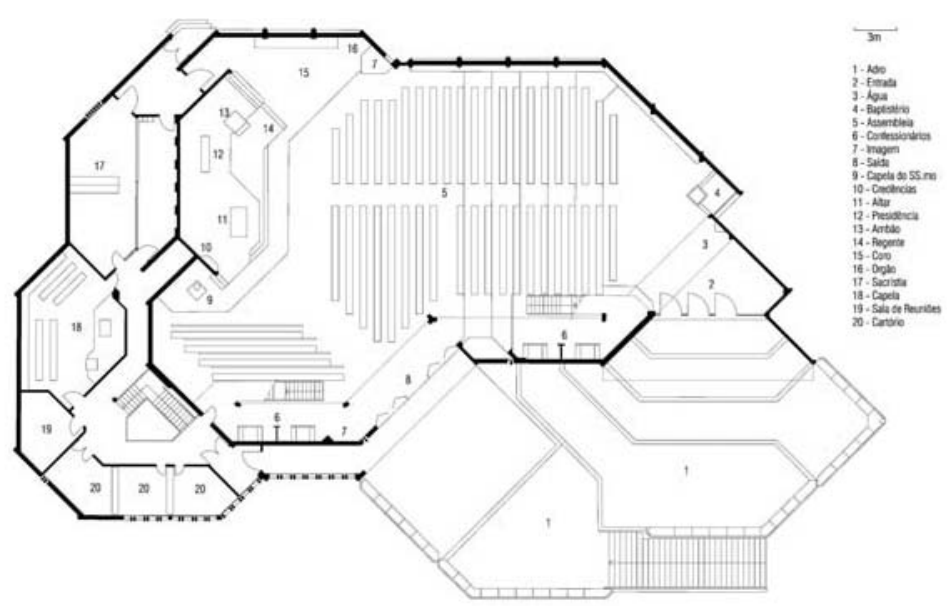

Nuno Teotonio Pereira y Luis Almeida Moreira, iglesia parroquial de Almada, 1965/67.

atmosphere for devotion, and this is enhanced by the controlled spatial proportions. The choir is located at the highest level, linking the presbytery to the assembly. The liturgical renewal is quite apparent in this 1962 church: the architect took it into account and studied it carefully.

The third and last church is the one in Almada. This is a different church in amphitheatre, with several levels (four). The new liturgy has been fully implemented and the altar, pulpit, presidential chair, etc. are very carefully placed. There is even a precise seat for the choir conductor. The Holy Sacrament chapel is at one side. There is also a private chapel, catechesis rooms and an atrium. The austere armoured concrete with a very powerful texture must be highlighted, since all its surfaces are exposed. The zenith light openings provide the project with a great spatial unity.

To conclude, we may say that the main contents of the renewal of religious architecture in Portugal signified an intense relation among the cladding construction -something which particularly concerned this architect in his three churches-, the concept of sacred space - which I have tried to study and perceive in so many church documents-, the functions of the various celebration spaces, the techniques and materials used, the formal component and the plastic expression, also desired for the churches. en todas las superficies. Las entradas de luz cenital aportan una gran unidad espacial al proyecto.

Como conclusión, podemos decir que los principales contenidos de la renovación de la arquitectura religiosa en Portugal pasaron por una intensa relación de la construcción de la piel envolvente - algo que preocupó especialmente a este arquitecto en sus tres iglesias-, el concepto de espacio sagrado - que yo procuré estudiar y percibir en tantos documentos eclesiales - la función de los diferentes espacios de celebración, los materiales y técnicas utilizadas, el componente formal y la expresión plástica, que también se buscó para las iglesias. 